\title{
PERAN DANA DESA DALAM PEMBANGUNAN PERTANIAN DI DESA KAPUK KECAMATAN TABIR ULU KABUPATEN MERANGIN
}

\author{
THE ROLE OF VILLAGE FUNDS IN AGRICULTURAL DEVELOPMENT IN KAPUK \\ TABIR ULU VILLAGE, MERANGIN DISTRICT
}

\author{
Fikriman, Syaiful Amri, Widuri Susilawati
}

Program Studi Agribisnis, Fakultas Pertanian, Universitas Muara Bungo, Jl. Pendidikan, RT. 10 RW. 02 No. 10 Kelurahan Sungai Binjai. Kecamatan Bathin III. Kabupaten Bungo, Jambi 37228, Indonesia

manfikri@ymail.com, syaifulamri0902@gmail.com, widurisusilawati@gmail.com

\begin{abstract}
ABSTRAK
Penelitian ini dilaksanakan di Desa Kapuk Kecamatan Tabir Ulu Kabupaten Merangin pada bulan Desamber 2018 sampai Januari 2019, pemilihan lokasi ini dengan pertimbangan bahwa Desa Kapuk adalah desa dengan luas sawah terbesar di Kecamatan Tabir Ulu, dan Kecamatan Tabir Ulu merupakan kecamatan yang memiliki luas lahan karet terbesar di Kabupaten Merangin. penelitian ini dilakukan untuk mengetahui tingkat kepuasan masyarakat terhadap Dana Desa yang digunakan untuk pembangunan pertanian.

Metode pengambilan data yang digunakan dalam penelitian ini adalah teknik wawancara langsung kepada responden berdasarkan kuesioner yang di berikan kepada kepala keluarga di Desa Kapuk Kecamatan Tabir Ulu Kabupaten Merangin sebanyak 55 kepala keluarga.

Hasil penelitian menunjukan bahwa tingkat kepuasan masyarakat terhadap Dana Desa yang digunakan untuk pembangunan pertanian Tinggi.Berdasarkan jumlah skor tingkat kepuasan masyarakat terhadapa Dana Desa yang digunakan untuk pembangunan pertanian di Desa Kapuk yaitu sebanyak 863, yang mana kategori skor tingi yaitu 689 - 1100, maka dengan jumlah skor 863 dapat kita simpulkan bahwa jumlah skor tersebut termasuk kedalam kategori tinggi.
\end{abstract}

\section{Kata Kunci : Dana Desa, Pembangunan Pertanian Dan Tingkat Kepuasan}

\section{ABSTRACT}

This research was carried out in Kapuk Village, Tabir Ulu Subdistrict, Merangin District in December 2018 until January 2019, choosing this location with the consideration that Kapuk Village is the village with the largest rice field area in Tabir Ulu Subdistrict, and Tabir Ulu Subdistrict has the largest rubber land area in Merangin Regency. This research was conducted to determine the level of community satisfaction with the Village Fund used for agricultural development.

The data collection method used in this study was a direct interview technique to respondents based on a questionnaire given to the head of the family in Kapuk Village, Tabir Ulu District, Merangin District as many as 55 households.

The results showed that the level of community satisfaction with the Village Fund used for agricultural development was high. the total score of 863 we can conclude that the total score is included in the high category.

Keywords: Village Funds, Agricultural Development and Level of Satisfaction 


\section{PENDAHULUAN}

Berdasarkan pada Peraturan Pemerintah Nomor 60 Tahun 2014 Tentang Dana Desa yang bersumber dari Anggaran Pendapatan dan Belanja Negara, pada ayat pasal yang telah diamandemen pada Peraturan Pemerintah Nomor 168 tahun 2014 ke 11 ayat 2 yang menyatakan bahwa dana desa dialokasikan secara berkeadilan yaitu berdasarkan:Alokasi dasar, danAlokasi yang dihitung memperhatikan jumlah penduduk, angka kemiskinan, luas wilayah, dan tingkat kesulitan geografis desa setiap kabupaten/kota (Sukanto, 2003)

Dalam UU Nomor 6 Tahun 2014 tentang Desa, yaitu adanya komitmen negara dalam melindungi dan memberdayakan desa agar menjadi kuat, maju, mandiri dan demokratis sehingga dapat menciptakan landasan yang kuat dalam melaksanakan pemerintahan dan pembangunan menuju masyarakat yang adil makmur dan sejahtera.

Dalam operasionalisasi Desa untuk mewujudkan otonomi yang diberikan kepada Desa terdapat pembiayaan-pembiayaan, dimana pembiayaan tersebut memiliki hubungan dengan Alokasi Dana Desa, sehingga Pemerintah Daerah Kabupaten memberikan Alokasi Dana Desa kepada setiap Desa yang berada diwilayahnya. Hal ini tercantum pada Undang-Undang Nomor 6 Tahun 2014 tentang Desa yang menyebutkan bahwa keuangan Desa adalah semua hak dan kewajiban Desa yang dapat dinilai dengan uang serta segala sesuatu berupa uang dan barang yang berhubungan dengan pelaksanaan hak dan kewajiban Desa yang menimbulkan pendapatan, belanja, pembiayaan dan pengelolaan keuangan Desa.

Alokasi Dana Desa diberikan oleh pemerintah pusat yang di peroleh dari dana perimbangan Anggaran Pendapatan dan Belanja Negara (APBN) yang diterima oleh Kabupaten/Kota dalam Anggaran Pendapatan dan Belanja Daerah (APBD) setelah dikurangi Dana Alokasi Khusus (DAK) sebesar 10\%. Dana tersebut kemudian dapat digunakan untuk membiayai penyelenggaraan pemerintahan, pelaksanaan pembangunan, pembinaan kemasyarakatan dan pemberdayaan masyarakat. Jumlah nominal yang akan diberikan kepada masing-masing Desa akan berbeda tergantung dari geografis Desa, jumlah penduduk, serta jumlah angka kematian. Alokasi dana sebesar $10 \%$ yang diterima oleh Desa akan menyebabkan peningkatan terhadap pendapatan Desa.

Selain Alokasi Dana Desa, sumber keuangan desa juga meliputi Dana Desa. Dana Desa diperuntukkan bagi pelaksanaan pembangunan dan pemberdayaan masyarakat. Dalam pasal 4 (Peraturan Menteri Desa, Pembangunan Daerah Tertinggal, Dan Transmigrasi No 21 Tahun 2015 tentang Penetapan Prioritas Penggunaan Dana Desa Tahun 2015, 2016), ditegaskan Dana Desa diprioritaskan untuk membiayai pelaksanaan program dan kegiatan berskala lokal desa bidang pembangunan desa dan pemberdayaan masyarakat desa. Sasaran penggunaan Dana Desa adalah untuk memperbaiki kehidupan masyarakat desa, terutama dalam segi ekonomi, sosial, budaya dan politik. Partisipasi masyarakat merupakan salahsatu aspek utama dari penggunaan Dana Desa. Penggunaan dana desa dirumuskan dalam 
musyawarah desa, serta alokasi anggaran dimasukkan dalam APBDesa. Jika masyarakat menginginkan penggunaan di luar ketentuan tersebut, dapat dilakukan setelah mendapatkan persetujuan Bupati (Peraturan Menteri Keuangan No 93/PMK.07/2015 tentang Tata Cara Pengalokasian, Penyaluran, Penggunaan, Pemantauan, dan Evaluasi Dana Desa, 2015).

Salah satunya Kabupaten Merangin, Kabupaten Merangin adalah Kabupaten yang berada di Provinsi Jambi, kabupaten merangin memiliki 24 Kecamatan, dengan 24 Kecamatan tersebut tentu banyak Dana Desa yang diterima oleh Kabupaten Merangin,adapun jumlah Dana Desa Per Kecamatan di Kabupaten Merangin yaitu Rp 148.823.812.997, ,- dan diKecamatan Tabir Ulu mendapat Dana Desa sebanyak Rp 4.978.371.827.,-,atau 3,3 \% dari 24 Kecamatan Di Kabupaten Merangin, dari jumlah dana desa yang tersedia tersebut tentu ada yang digunakan untuk pertanian, contohnya jalan usaha tani, jalan usaha tani ini sangat lah bermanfaat bagi masyarakat yang berusaha tani karet, karena dapat mempermudah transportasi masyarakat dalam berusahatani. Luas tanaman karet di Kabupaten Merangin pada thun 2017 yaitu $19.066 \mathrm{Ha}$, Sedangkan luas tanaman karet terluas yaitu terdapat pada Kecamatan Tabir Ulu dengan jumlah 2.488 Ha. Dari jumlah luas tanaman karet tersebut tentu harus ada sarana dan prasarana yang dibuat untuk mempermudah masyarakat dalam berusaha tani.

Di Kecamatan Tabir Ulu Kabupaten Merangin Tahun 2018, mendapat Dana Desa sebanyakRp 4.978.371.827.,- .dan Desa Kapuk adalah Desa nomor dua terbanyak yang diberikan Dana Desa dengan jumlah Rp.
988.363.117,- $\quad$ atau19,8 \%.Pada penelitian ini mengkaji Dana Desa yang digunakan untuk sektor pertanian pada wilayah Desa Kapuk yang merupakan salah satu desa yang ada di Kecamatan Tabir Ulu Kabupaten Merangin yang telah menerima Dana Desa.

Penelitian ini betujuan untuk mengetahui apa saja yaang dibangun dari dana desa, seberapa banyak dana desa di gunakan, faktor penghambat dari dana desa, mengetahui tingkat kepuasan masyarakat dan implikasi positif dan negatif dari pembangunan Dana Desa yang digunakan untuk pertanian di Desa Kapuk Kecamatan Tabir Ulu Kabupaten Merangin. Dari ulasan tersebut maka penulis membuat judul "Peran Dana Desa Dalam Pembangunan Pertanian Didesa Kapuk Kecamatan Tabir Ulu Kabupaten Merangin Tahun 2018 “.

\section{METODELOGIPENELITIAN}

Penelitian ini dilaksanakan diKecamatan Tabir Ulu Kabupaten Merangin, lokasi ini dipilih karenaKecamatan Tabir Ulu merupakan kecamatan yang memiliki luas tanaman karet terbesar di Kabupaten Merangin, tepatnya penelitian ini dilaksanan di Desa Kapuk, karena Desa Kapuk merupakan wilayah sawah terluasdi Kecamatan Tabir Ulu, penelitian ini dilaksanakan pada bulan Desember 2018. Data dan informasi mengenai dana desa yang digunakan untuk sektor pertanian didasarkan pada dua jenis data yaitu data primer dan data sekunder.

Metode yang digunakan dalam peneliti ini adalah metode survey. Dalam melaksanakan metode ini, peneliti terjun langsung guna mendapatkan data yang diperlukan, karena metode ini memerlukan ini responden dan kosioner yang 
difokuskan kepada masyarakat Desa Kapuk Kecamatan Tabir Ulu Kabupaten Merangin. Responden dalam penelitian ini adalah Kepala Keluarga di Desa Kapuk Kecamatan Tabir Ulu Kabupaten Merangin dengan jumlah kepala desa secara keseluruan 548 orang, sehingga diambil sampel sbesar $10 \%$ kerana apa bila jumlah responden lebih dari seratus, maka pengambilan sampel $10 \%-15 \%$ atau $20 \%-25 \%$ atau lebih. (Arikunto, 2002), sehingga jumlah Responden dalam penelitian ini adalah 55 Kepala Keluarga.

Metode analisis data dalam penelitian ini adalah : Tujuan 1, 2 dan 4 Yaitu Dengan Cara Metode Deskriptif. Sedangan untuk menjawab tujuan no 3 yaitu untuk mengitung tingkat kepuasan masyarakat di Desa Kapuk Kecamatan Tabir Ulu Kabupatn Merangin, untuk menghitung tingkat kepuasan tersebut maka dapat lah rumus.Singarimbun Dan Efendi ( 1995 ).

Inerval Skor

Nilai Skor Maksimum - Nilai Skor Minimum

$=\frac{\text { Kategori }}{\text { Katlai Skor Maksimum }}$

Interval Skor

Skor maksimum $\mathrm{x}$ jumlah pertanyaan $\mathrm{x}$ jumlah responden

$=-\underline{\text { Skor minimum } \mathrm{x} \text { jumlah pertanyaan } \mathrm{x} \text { jumlah responden }}$ Kategori
Tabel 1. Indikator Tingkat Kepuasan Masyarakat Terhadap Dana

Desa Yang Digunnakan

Dalam Pembangunan

Pertanian.

\begin{tabular}{lllc}
\hline $\mathrm{N}$ & Indikator & \multicolumn{2}{c}{ Skor } \\
$\mathrm{O}$ & \begin{tabular}{l} 
tingkat \\
krepuasan \\
masyarakat \\
Terhadapa \\
penggunaan \\
\cline { 3 - 4 }
\end{tabular} & Mini & Maksimu \\
& mum & $\mathrm{m}$ \\
\hline 1 & Pertanyaan 1 & 1 & 4 \\
2 & Pertanyaan 2 & 1 & 4 \\
3 & Pertanyaan 3 & 1 & 4 \\
4 & Pertanyaan 4 & 1 & 4 \\
5 & Pertanyaan 5 & 1 & 4 \\
\hline & Total skor & 5 & 20 \\
\hline
\end{tabular}

$\begin{aligned} \text { Interval Skor } & =\frac{20-5}{2} \\ & =8\end{aligned}$

Jumlah kategori yang mempengaruhi tingkat kepuasan masyarakat adalah sebanyak dua kelas yaittu tinggi dan rendah. Hasil tersebut digunakan untuk menentukan tingkat kepuasan masyarakat :

- Skor 14-20 kategori tinggi

- Skor 5-13 kategori rendah

Jumlah skor untuk menghitng tingkat kepuasan masyarakat berdasarkan jumlah responden yaitu sebagai berikut :

$$
\begin{aligned}
\text { Interval Skor } & =\frac{4 \times 5 \times 55-1 \times 5 \times 55}{2} \\
\text { Interval Skor } & =\frac{1100-275}{2} \\
& =413
\end{aligned}
$$

Skor 689 - 1100 Kategori Tinggi

Skor 275 - 688 Kategori Rendah 


\section{HASIL DAN PEMBAHASAN}

\section{Pembangunan Pertanian Yang Bersumber Dari Dana Desa Yang Digunakan Untuk Pembangunan Pertanian di Desa Kapuk Tahun 2018}

Dalam menciptakan masyarakat yang sejahtera tentu harus didukung dengan pembangunan yang memadai, salah satunya pembangunan pertanian, hal ini sangat penting karena sangat berpengaruh terhadap perekonomian masyarakat, terutama masyarakat desa, jadi dengan adanya Dana Desa pemerintah di tuntut untuk mensejahterakan masyarakatnya. Desa Kapuk mendapat dana desa sebesar Rp. 988.363.117,-,dengan jumlah Dana Desa yang besar tersebut tentu sangat banyak yang bisa dibangun atau melakukan kegiatan kegiatan yang bertujuan untuk kesejahteraan masyarakat.

Pembangunan

pertanian, pembanguan pertanian sangat penting karena pertanian itu adalah sumber bahan pangan bagi masyarakat Indonesia, jadi hal ini sangat perlu ditingkatkan agar terciptanya masyarakat yang sejahtera makmur dan tenteram, jadi dengan adanya Dana Desa tersebut pemerintah desa dituntut untuk mentransfarankan hal tersebut supaya tidak terjadi kesalahpahaman antara masyarakat degan Pemerintah Desa, kalau Pemerintah Desa dengan masyarakatnya transparan tentu hal ini sangat baik, karena untuk menjalin komunikasi yang baik itu harus transparan supaya terciptanya keharmonisan diantara masyarakat dan Pemerintah Desa.

Dana Desa di Desa Kapuk digunakan untuk kegiatan - kegiatan yang bertujuan untuk mensejahterakan masyarakat, salah satunya pemanfaatan Dana Desa digunakan untuk pembangunan pertanian. Pada Tahun 2018 realisasi Dana Desa di Desa Kapuk sebesar Rp. 988.363.117,sedangkan anggarannya sebesar Rp. 988.363.117,-, jadi jumlah Dana Desa di Desa Kapuk Tahun 2018 terealisasi sebesar 100 \%. Dana Desa Di Desa Kapuk untuk Tahun 2018 yang digunakan utuk pembangunan pertanian sebesar Rp. 186.938.000,- atau 19,24 \% dari jumlah keseluruhan Dana Desa.Adapun rincian Dana Desa yang digunakan untuk pembangunan pertanian di Desa Kapuk Kecamatan Tabir Ulu Kabupaten Merangin yaitu sebagai berikut :

Tabel 2. Realisasi Dana Desa Yang Digunakan Untuk Pembangunan Pertanian DiDesa Kapuk Tahun 2018

\begin{tabular}{|c|c|c|c|}
\hline $\begin{array}{l}\mathrm{N} \\
\mathrm{O}\end{array}$ & $\begin{array}{c}\text { Nama } \\
\text { kegiatan }\end{array}$ & Jumlah ( Rp & $\begin{array}{c}\text { Persenta } \\
\text { se }(\%)\end{array}$ \\
\hline 1 & $\begin{array}{c}\text { Jalan } \\
\text { Usahata } \\
\text { ni } \\
\text { Lubuk } \\
\text { Punai }\end{array}$ & $\begin{array}{c}89.300 .000,0 \\
0\end{array}$ & $\begin{array}{l}47 \\
76\end{array}$ \\
\hline 2 & $\begin{array}{c}\text { Jalan } \\
\text { usahata } \\
\text { ni } \\
\text { Ganduk }\end{array}$ & $\begin{array}{c}97.638 .000,0 \\
0\end{array}$ & $\begin{array}{l}52 \\
23\end{array}$ \\
\hline & Jumlah & $\begin{array}{c}186.938 .000 \\
00\end{array}$ & 100 \\
\hline
\end{tabular}

Sumber : Analisis data 2018

Dari Tabel 2 dapat kita lihat bahwa Dana Desa yang digunakan untuk pembangunan pertanian sebesar Rp.186.938.000,00,- ataudari jumlah keseluruhan tersebut, 47,76 \% digunakan untuk pembangunan Jalan Usaha Tani Lubuk Punai, dan 52,23 \% 
digunakan untuk Jalan Usaha Tani Ganduk. hal tersebut sangatlah berguna bagi masyarakat karena mayoritas penduduk Desa Kapuk adalah bertani, maka dengan adanya pembangunan tersebut tentu sangat bermanfaat bagi masyarakat terutama petani.

Penggunaan Dana Desa untuk pembangunan pertanian di Desa Kapuk Tahun 2018 masih kecil atau 19,24\% dari keseluruhan Dana Desa, hal ini sangat erat kaitannya terhadap kesejahteraan masyarakat karena mayoritas penduduk Desa Kapuk adalah bertani, pembangunan pertanian di Desa Kapuk perlu ditingkatkan, karena pembangunan pertanian sangat besar perannya terhadap perekonomian masyarakat terutama petani, mengingat hampir $91 \%$ kepala keluarga di Desa Kapuk bekerja di sektor pertanian.

\section{Faktor Penghambat Dalam Pelaksanaan Dana Desa Yang Digunakan Untuk Pertanian}

Faktor - faktor yang menghambat pelaksanaan pembangunan pertanian yang bersumber dari Dana Desa di Desa Kapuk yaitu sebagai berikut :

\section{A. Iklim}

Iklim merupakan salah satu faktor yang sangat berpengaruh terhadap pelaksanan / pembangunan Dana Desa yang diguakan untuk pertanian, hal ini disebabkan karena pembanguan pertanian di Desa Kapuk pada Tahun 2018 dilaksanakan bertepatan dengan musim hujan, maka dalam membawa material untuk pembangunan pertanian sangat susah karena hal ini disebabkan oleh jalan yang belum memadai atau masih dalam keadaan becek, pada Tahun 2018 ini masyarakat kebanyakan mengambil material didesa ini saja, salah satunya pasir, pasir terletak diseberang sungai maka transportasi kesana sangat sulit, sehingga dapat memperlambat masyarakat dalam membawa material ke daerah yang akan dibangun melalui Dana Desa tersebut, dan pada Tahun 2018 juga terjadi musim kemarau pada saat pelaksanaan pembangunan melalui Dana Desa tersebut, musim kemarau juga dapat berkendala tentang masalah air, air ini sangat penting dalam pembangunan pertanian, salah satunya dalam pembuatan jalan usahatani, kalau tidak ada air maka proses pembangunan untuk jalan usahatani tersebut pun terhambat, dan juga apabila kekurangan air maka hal ini sangat berpengaruh terhadap ketahan dari jalan tersebut, hal ini lah yang menyebabkan air itu sangat berpengaruh terhadap pembangunan pertanian.

\section{B. Manusia}

Manusia sangat penting perannya dalam pembangunan untuk pertanian tersebut, karena manusia adalah orang yang mengoperasikan pembangunan tersebut, kalau tidak ada manusia maka hal tersebutpun tidak akan terjadi. Salah satunyaSkill, kalau manusia yang mengerjakan pembangunan tersebut tidak mempunyai Skill yang terampil, maka yang akan terjadi yaitu, kurang tahannya sarana dan prasarana tersebut dikarenakan belum punya skill yang memadai..

Skill yaitu kemampuan seseorang dalam melakukan suatu hal atau kegiatan, salah satunya dalam melakukan pembuatan jalan usaha tani, apa bila orang yang melakukan pembuatan jalan usahatani tersebut memiliki Skill yang rendah, maka hal ini sangat berpengaruh terhadap ketahanan jalan tersebut, mengapa demikian, karena untuk menciptakan jalan usahatani yang bagus dan tahan 
lama diperlukan Skill yang terampil, supaya kualitas dari pembuatan jalan tersebut pun sangat baik dan tahan lama.

Masyarakat yang mengerjakan jalan usahatani di Desa Kapuk Tahun 2018 ini Skill nya masih rendah, karena dari jalan yang dibuat tersebut terlihat masih belum berkualitas, salah satu hal yang belum berkualitas dari kinerja masyarakat tersebut yaitu dapat dilihat di pembuatan jalan usaha tani yang kekurangan semen, sehingga hal ini sangat berpengaruh terhadap ketahanan dari jalan usahatani tersebut, maka dari itu perlu ditingkatkan Skill supaya jalan usahatani terealisasi dengan baik.

Pemerintah Desa dituntut untuk mengadakan pemberdayaan masyarakat, terutama di bidang pembangunan jalan usahatani, supaya terciptanya skill yang berkualitas atau terampil, hal ini pun bisa berguna untuk pembangunan pembangunan yang akan datang agar terciptanya pembangunan yang memadai dan tahan lama, sekaligus menambah ilmu dan pengetahuan masyarakat supaya terciptanya masyarakat yang sejahtera.

\section{Teknologi}

Teknolgi merupakan hal yang sangat penting perannya dalam pembangunan, karena melalui teknologi bisa menghasilkan hasil yang maksimum atau terealisasi dengan baik, didalampembangunan jalan usahatani di Desa Kapuk Tahun 2018juga mengalami kendala pada teknologi yang digunakan, adapun permasalahan yang di hadapi yaitu untukpelaksanaan pembuatan jalan usahatani masih menggunakan cara manual, salah satunya seperti pengadukan semen yang masih menggunakan cara manual atau masih menggunakan tenaga manusia, hal ini sangat berpengaruh karena bisa memperlambat akan jadinya pembangunan, maka proses nya akan memakan waktu yang banyak, otomatis upah yang dikeluarkan untuk pekerja pun bertambah, dan mungkin cara ini sangatlah kuno, dan yang akan terjadi pun bisa seperti munculnya uang tak terduga, karena sudah memakan waktu yang sangat lama dan upah pekerjapun bertambah atau meningkat.

Pemerintah Desa dituntut untuk mengadakan sarana dan prasarana yang baik supaya terciptanya jalan usahatani yang bagus serta tidak memakan waktu yang sangat lama. Tapi kalau pembangunan tersebut menggunakan alat yang canggih salah satunya yaitu mesin molen ( mesin pengaduk semen ) otomatis hal ini tidak akan memakan waktu yang lama karena yang berkerja adalah mesin, dari pekerja yang dulunya susah dalam mengaduk semen, maka dengan adanya mesin ini maka pekerjapun tidak susah lagi untuk mengaduk semen, dan juga tidak memakan waktu yang lama, dan upah pekerjanya pun cukup sedikit saja .

\section{Tingkat Kepuasan Masyarakat Terhadap Dana Desa Yang Digunakan Untuk Pembangunan Pertanian}

Di dalam melakukan suatu pembangunan pertanian tentu banyak respon dari masyarakat, salah satunya kepuasan masyarakat terhadap pembangunan tersebut, adapun tingkat kepuasan masyarakat terhadap pembangunan pertanian yang ada di Desa Kapuk Kecamatan Tabir Ulu Kabupaten Merangin Tahun 2018 yaitu sebagai berikut : 
Tabel 3. Tingkat

Kepuasan

Masyrakat Terhadap Dana

Desa Yang Digunakan Untuk

Pembangunan Pertanian Di

Desa Kapuk Tahun 2018

\begin{tabular}{cccc}
\hline No & Skor & Jumlah & $\begin{array}{c}\text { Pesentase } \\
(\%)\end{array}$ \\
\hline 1 & Tinggi & 44 & 80 \\
2 & Rendah & 11 & 20 \\
\hline & Jumlah & 55 & 100 \\
\hline
\end{tabular}

Sumber : Analisis Data 2018

Dari Tabel 3 dapat kita lihat bahwa dari 55 responden ada 44 responden yang termasuk kategori skor tinggi yaitu sebanyak $80 \%$, hal ini menunjukan bahwa tingkat kepuasan masyarakat terhadap pembangunan jalan usahatani tinggi.

Adapun data tingkat kepuasan masyarakat berupa skor dari angket kuesioner dapat di lihat pada lampiran 3 , berdasarkan data tersebut dapat dilihat bahwa dari 55 responden dapat dihasilkan nilai tingkat kepuasan masyarakat sejumlah 863. Dari perhitungan nilai interval bahwa untuk jumlah skor nilai sejumlah $689-1100$ dalam kategori tinggi dan skor 275 688 kategori rendah, maka dari itu dapat kita simpulkan bahwa tingkat kepuasan masyarakat terhadap Dana Desa yang digunakan untuk pembangunan pertanian di Desa Kapuk pada Tahun 2018 tinggi.

Masyarakat menjawab puas karena sarana dan prasarana yang dibangun untuk pembangunan pertanian telah sesuai atau telah terealisasi dengan baik, salah satunya jalan usahatani yang selama ini belum ada atau belum terealisasi maka dengan adanya Dana Desa tersebut jalan usahatanipun dibangun untuk melancarkan transportasi usahatani masyarakat, dan juga masyarakat mengatakan puas terhadap penggunaan Dana Desa yang digunakan untuk pembangunan pertanian ini karena masyarakat merasa keinginan masyarakat telah terpenuhi dan juga tingkat partisipasi masyarakat terhadap pembangunan tersebutpun tinggi, pembangunan tersebutpun betulbetul bermanfaat, hal ini bermanfaat karena selama ini masyarakat yang dulunya susah dalam melakukan transportasi usahtani maka dengan adanya pembangunan jalan usaha tani tersebut masyarakat bisa lebih leluasa dalam melakukan transportasi usahatani dari luar sampai kelahan usaha tani dan membawa hasil produksi usahatani keluar dari lahan pun menjadi mudah, hal-hal tersebutlah yang menyebabkan masyarakat Desa Kapuk menjawab puas terhadap Dana Desa yang digunakan untuk pembangunan pertanian, jadi karena hal itulah tingkat kepuasan masyarakat tersebut tinggi.

\section{Implikasi Positif Dan Negatif Dari Dana Desa Yang Digunakan Untuk Pembangunan Pertanian \\ Dalam melakukan suatu} pembangunan tentu ada implikasi positif dan negatif, salah satunya pembangunan pertanian, pembanguan pertanian ini bersumber dari adanya Dana Desa, adapun implikasi tersebut yaitu sebagai berikut :

\subsection{Implikasi Positif}

a. Lancarnya Transportasi Untuk Usaha Tani

Pembanguan sarana dan prasarana sangat penting untuk meningkatkan kelancaran dalam berusaha tani, tanpa sarana dan prsarana yang memadai, harga komoditas yang diproduksi oleh petani pun akan bernilai rendah karena biaya angkutan yang mahal, salah satunya dalam membawa 
hasil produksi padi, di dalam Tahun 2018 ini masyarakat mudah melakukan transportasi usahatani karena jalan usahatani telah terealisasi oleh Dana Desa yang digunakan untuk pembangunan pertanian, kalau jalan usahatani masih belum memadai, maka masyarakatpun perlu meningkatkan biaya untuk pengangkutan hasil produksinya, yang sebelumnya masih menggunakan ojek padi, jadi dengan adanya jalan ushatani yang sudah terealisasi tersebut, maka masyarakat tidak perlu lagi untuk mengeluarkan biaya upah untuk ojek padi, mereka bisa membawa hasil produksinya sendiri karena jalan usahatani sudah memadai.

Hal positif inilah yang sangat nampak dari penggunan Dana Desa yang digunakan unutuk pertanian, karena dari masyarakat yang dulunya susah dalam dalam melakukan transportasi ushatani, salah satunya dalam pengangkutan hasil produksi usahatani masyarakat yang sering terjadi kerugian karena jalan yang belum memadai atau terealisasi, maka dengan adanya pembangunan jalan uahatani masyarakat bisa leluasa untuk melakukan transportasi usahatani, baik itu untuk membawa hasil produksi ushatani keluar lahan maupun membawa sarana dan prasarana ke lahan usahatani, hal ini juga berperan bisa untuk meningkatkan hasil produksi usahatani yang ada di Desa Kapuk.

\section{b.Meningtatkan Produktivitas Hasil Petani}

Dengan adanya pembangunan jalan usahatani yang memadai maka hal ini sangat besar pengaruhnya bagi masyarakat, akses jalan tersebut mempermudah petani dalam membawa sarana produksi seperti benih, pupuk kandang, pupuk organik, atau sarana pertanian lainnya,serta produksi hasil petani meningkat, petani yang dulunya bercocok tanam secara manual atau tradisional, maka dengan adanya jalan usahatani maka alat atau mesin pertanian pun bisa dibawa untuk meningkatkatkan produktivitas petani.

Petani yang dulunya selalu rugi dalam melakukan transportasi usahatani yaitu dalam pengangkutan hasil usahatani masyarakat sering terjadi kerusakan atau menyusutnya hasil produksi masyarakat, salah satunya dalam membawa hasil usahatani padi, dari padi yang dulunya sering mengalami kerusakan, dengan rusaknya jalan yang merupakan akses transportasi usahatani akan mengakibatkan naiknya biaya angkut, maka dengan adanya pembangunan jalan usahatani tersebut, padi atau hasil usahatani dari masyarakat dapat dibawa dengan baik, hal ini lah yang menyebabkan produktivitas petanipun meningkat dan biaya angkut hasil usahatani menjadi menurun.

\subsection{Implikasi Negatif}

Pembangunan jalan usahatani di Desa Kapuk berfungsi sebagai lancarnya transportasi petani dalam berusahatani, hal tersebut juga bisa menyebabkan pencurian atau curanmor, karena pelaku sudah mudah untuk menjalankan aktivitas tersebut mengingat sarana dan prasarana jalan usahatani sudah memadai, atau terealisasi, karena hal inilah pencurian pun terjadi.

Desa Kapuk adalah desa yang mempunyai luas sawah terbesar di Kecamatan Tabir Ulu Kabupaten Merangin, maka demgan adanya Dana Desa dibangunlah jalan usahatani, dengan lancarnya transportasi masyarakat dalam berusahatani maka, hal ini dapat menimbulkan keinginan 
untuk melakukan tindak kejahatan berupa pencurian kendaraan dari si petani tersebut, hal ini disebabkan karena masyarakat umumnya melatakan kendaraannya dipinggir jalan usahatani, jalan usahatani yang sudah dibangun umumnya hanya kelokasi sawah atau lahan usahatani, dari jalan usahatani ke huma petani pun belum tersedia, sehingga kendaraan petani di letakan di pinggir jalan usahatani. Dengan terparkirnya kendaraan milik petani di pinggir jalan usahatani maka, hal tersebut menimbulkan keinginan seseorang untuk melakukan tindak kejahatan berupa pencurian di jalan usahatani tersebut.

Jadi kepada masyarakat khususnya masyarakat Desa Kapuk kecamatan Tabir Ulu Kabupaten Merangin dituntut untuk bisa lebih hatihati dalam melatakkan kendaraannya supaya tidak terjadi hal yang tak di inginkan.

\section{KESIMPULAN DAN SARAN}

\section{Kesimpulan}

Dari hasil penelitian tersebut dapat di simpukan bahwa :

1. Dana Desa di Desa Kapuk Kecamatan Tabir Ulu Kabupaten Merangin pada Tahun 2018 digunakan untuk pembangunan serta kegiatan yang bertjuan utuk mensejahterakan masyrakat. Dana Desa yang gunakan untuk pertanian yaitu sebesar Rp. 186.938.000,atau 19,24 \% dari jumlah keseluruhann Dana Desa.

2. Faktor pengambat dalam pelaksanaaan Dana Desa yang digunakan untuk pembangunan pertanian di Desa Kapuk yaitu Iklim, Manusia, dan Teknologi.
3. Tingkat kepuasan masyrakat terhadap Dana Desa yang digunakan untuk pembangunan pertanian tinggi, hal ini dapat kita lihat bahwa jumlah skor tingkat kepuasan masyarakat terhadap Dana Desa yang digunakan untuk pembangunan pertanian yaitu 863 , sedangkan skor kategori tinggi yaitu 689 - 110, jadi dari hasil jumlah keseluruhan skor yaitu 863, maka dapat kita simmpulkan bahwa tingkat kepuasan masyarakat terhadap Dana Desa yang digunakan untuk pembangunan pertanian tinggi.

4. Implikasi positif dan negatif dari Dana Desa yang digunakan untuk pembangunan pertanian yaitu :

- Implikasi Positif

a) Lancarnya transportasi untuk usaha tani

b) Meningkatkan produktivitas hasil petani

- Implikasi Negatif

Implilasi negaif dari Dana Desa yang digunakan untuk pembangunan pertanian di Desa Kapuk yaitu curanmor atau pencurian kendaraan milik petani.

\section{Saran}

1. Pembangunan pertanian di Desa Kapuk perlu ditingkatkan karena pembangunan pertanian sangat penting perannya terhadap perekonomian masyarakat terutama petani, mengingat hampir 91 kepala keluarga di Desa Kapuk bekerja di sektor pertanian.

2. Pemerintah Desa dituntut untuk mengadakan pemberdayaan masyrakat terutama di bidang pembangunan jalan usahatani, supaya terciptanya skill yang berkualitas atau terampil agar 
terciptanya masyarakat yang sejahtera.

3. Masyarakat di Desa Kapuk dituntut untuk lebih berhati-hati dalam meletakkan kendaraan usaha tani mereka supaya tidak terjadi hal yang tak di inginkan.

\section{DAFTAR PUSTAKA}

APBD (Anggaran Pendapatan Belanja Desa) Desa Kapuk Tahun 2018

Arikunto, 2002. Prosedur Penlitian Suatu Pendekatatan Praktek, PT. Rineka Cipta.Jakarta

BPS (Badan Pusat Statistik) Kabupaten Merangin Luas Tanaman Karet Perkecamatan Di Kabupaten Merangin Tahun 2017

DPMPD ( Dinas Pemberdayaan Masyarakat Desa ) Kabupaten Merangin jumlah Dana Desa Dikabupaten Merangin Tahun2018.Jumlah Dana Desa Di Kecamatan Tabir Ulu Kabupaten Merangin

Peraturan Pemerintah Nomor 60 Tahun 2014 Tentang Dana Desa Yang Bersumber Dari Anggaran Pendapatan Dan Belanja Negara, Pada Ayat Pasal Yang Telah Diamandemen Pada Peraturan Pemerintah Nomor 168 Tahun 2014 Ke 11 Ayat 2.

Programa Penyuluh Tanaman Pangan Dan Holtikultur Uptd Wilayah Ix Kecamataan Tabir Ulu Kabupaten Merangin
Singarimbun, Mdan Sofian E, 1995. Metode Penelitian Survei: Pustaka LP3ES. Jakarta

Soekanto, S (1990) Sosiologi Suatu Ilmu Pengantar, ( Rajawali Pres Jakarta)

Sukanto, A 2014.Efektifitas Alokasi Dana Desa (Add) Dan Kemiskinan Di Provinsi Sumatera Selatan, Jurnal Ekonomi Pembangunan, Volume 12,No.1

Undang - Undang Nomor 17 Tahun 2003 Tentang Belanja Negara

Undang-Undang Nomor 33 Tahun 2004 Tentang Perimbangan Keuangan Pusat Daerah.

Undang-Undang Nomor 6 Tahun 2014

Undang-Undang Nomor 6 Tahun 2014 Pasal 1 Tentang Desa 